\title{
Terapi Antibiotika pada Pneumonia Usia Lanjut
}

\author{
Roza Mulyana
}

\begin{abstract}
Abstrak
Pneumonia merupakan infeksi yang sering ditemukan pada usia lanjut. Berbagai faktor dapat meningkatkan risiko usia lanjut mengalami pneumonia, diantaranya perubahan sistem imun, multipatologi, dan penurunan status fungsional. Dalam memilih antibiotika bagi pasien usia lanjut dengan pneumonia, diperlukan berbagai pertimbangan diantaranya jenis pneumonia apakah di komunitas atau nosokomial, beratnya pneumonia yang dideritanya, dan status frailty pasien usia lanjut. Pilihan antibiotika awal yang diberikan tergantung jenis dan berat pneumonia, status frailty, dan faktor risiko yang mendasari penderita mengalami infeksi organisme tertentu. Dosis antibiotika yang diberikan disesuaikan dengan laju filtrasi glomerulus.
\end{abstract}

Kata kunci: pneumonia, usia lanjut, antibiotika

\begin{abstract}
Pneumonia is still common infection affected elderly patients. Many factors could be risk factors for pneumonia such as immunosenescence, morbidities, and functional impairment. Antibiotic for elderly patients with pneumonia is important. The first choice of antibitotics depends on pneumonia severity, frailty, and risk factors for specific microorganisms. The doses of antibiotics adjusted with individual glomerular filtration rate.
\end{abstract}

Keywords: pneumonia, elderly, antibiotic

Affiliasi penulis: Subbagian Geriatri Bagian IImu Penyakit Dalam Fakultas Kedokteran Universitas Andalas/RSUP dr.M.Djamil Padang Korespondensi: rozamulyana@med.unand.ac.id Telp: 081374859840

\section{PENDAHULUAN}

Pneumonia merupakan salah satu infeksi yang sering ditemukan pada usia lanjut. Terdapat lebih dari sejuta kasus pneumonia yang memerlukan perawatan di Amerika Serikat, 600.000 kasus di antaranya pada pasien di atas 65 tahun. Pneumonia pada usia lanjut berkaitan dengan meningkatnya morbiditas, mortalitas, dan terganggunya status fungsional. Sekitar 10-20\% pasien memerlukan perawatan di Intensive Care Unit. Angka mortalitas 30 hari usia lanjut dengan komorbiditas berat sekitar 25-50\%, ${ }^{1}$ sedangkan pada usia 85 tahun ke atas mortalitas tiga kali lebih tinggi ${ }^{2}$. Rehospitalisasi terjadi pada $20 \%$ pasien. $^{1}$

Usia lanjut mengalami berbagai perubahan fisiologis terkait proses penuaan. Berbagai faktor menjadi penyebab meningkatnya kejadian pneumonia pada usia lanjut, di antaranya perubahan sistem imun, baik sistem imun alami maupun adaptif. Terjadi gangguan barier mekanik, aktivitas fagositik, imunitas humoral dan sel T, serta penurunan fungsi sel natural killer, makrofag, dan neutrofil. ${ }^{3,4} \mathrm{Hal}$ ini juga diperberat dengan kondisi multipatologi yang sering dialami seorang usia lanjut.

Berbagai penelitian dengan metode yang berbeda telah mengidentifikasi faktor-faktor risiko terjadinya pneumonia pada usia lanjut. Faktor-faktor risiko tersebut di antaranya penyakit paru yang diderita, penyakit jantung, penurunan berat badan, status fungsional yang jelek, merokok, gangguan menelan, aspirasi, malnutrisi, hipoproteinemia, hipoalbuminemia, terapi antibiotik sebelumnya, kualitas hidup yang rendah, dan status bedridden. Riwayat dirawat karena pneumonia dalam 2 tahun terakhir, diabetes melitus, immunosupresi, penyakit ginjal, konsumsi alkohol berlebihan, penggunaan obatobat antipsikotik, kondisi sosio-ekonomi dan kontak dengan anak-anak juga meningkatkan risiko terjadinya pneumonia pada usia lanjut. $^{3}$ 
Pemberian antibiotika dapat mempengaruhi hasil pengobatan pasien dengan pneumonia. Meskipun banyak faktor lain yang mempengaruhi keberhasilan pengobatan pada usia lanjut seperti komorbiditas dan status fungsional, pemilihan antibiotika yang tepat diharapkan dapat menurunkan angka morbiditas dan mortalitas.

\section{Perubahan pada Sistem Respirasi Terkait Penuaan}

Seiring penuaan, terjadi berbagai perubahan pada sistem respirasi. Terjadi penurunan elastisitas paru, meningkatnya kekakuan dinding dada, dan berkurangnya kekuatan otot dada. Selain itu juga terjadi penurunan gerak silia pada sistem respirasi, penurunan refleks batuk, dan refleks fisiologik lainnya yang dapat meningkatkan risiko terjadinya infeksi pada saluran napas bawah. ${ }^{5}$ Volume residu paru bertambah dan terjadi penurunan sensitivitas pusat pernapasan terhadap hipoksemia dan hiperkapnia. ${ }^{1}$

\section{Pneumonia pada Usia Lanjut}

Beberapa penelitian terdahulu menunjukkan Streptococcus pneumonia sebagai penyebab tersering pneumonia komunitas pada usia lanjut, yaitu sekitar $36-49 \%$. $^{3}$ Berbeda dengan penelitian Han et al. yang mendapatkan Pseudomonas aeruginosa sebagai penyebab tersering pneumonia komunitas di China, yaitu sebesar $20,1 \%$, diikuti Klebsiella pneumonia $15,2 \%$, Streptococcus pneumonia hanya ditemukan sebanyak $3,3 \%{ }^{2}$

Pneumonia pada usia lanjut seringkali tidak menunjukkan gejala yang jelas. Beberapa penelitian menunjukkan tidak selalu ditemukan demam ataupun gejala pernapasan pada populasi ini. Penelitian Fernandez-Sabe et al terhadap pasien pneumonia komunitas berusia 80 tahun ke atas tidak menemukan keluhan batuk sebagai keluhan pasien saat masuk perawatan, sedangkan demam tidak didapatkan pada $32 \%$ pasien. $^{6}$ Zalacain et al mendapatkan perubahan status mental sebagai keluhan utama pada $26 \%$ pasien. ${ }^{7}$ Selain perubahan status mental atau perilaku, usia lanjut bisa datang dengan keluhan jatuh, gangguan status fungsional, dizziness, penurunan kesadaran, kelemahan umum, anoreksia, dehidrasi atau inkontinensia. ${ }^{1}$ Manifestasi klinis yang tidak biasa ini seringkali menyebabkan keterlambatan diagnosis pneumonia pada usia lanjut. $^{3}$

\section{Pneumonia Komunitas (Community Acquired Pneumonia)}

Pneumonia komunitas adalah infeksi pneumonia yang didapat di luar rumah sakit atau fasilitas kesehatan. Untuk menentukan kriteria pasien yang dirawat atau dapat menjalani rawat jalan dapat digunakan sistem skor CURB-65. Pada penilaian menggunakan CURB-65 terdapat 5 item penilaian di antaranya confusion (perubahan kesadaran), kadar ureum yang meningkat, frekuensi pernapasan yang meningkat ( $\geq 30 \mathrm{kali} / \mathrm{menit}$ ), tekanan darah sistolik $<90$ $\mathrm{mmHg}$ atau diastolik $\leq 60 \mathrm{mmHg}$, dan usia (usia $\geq 65$ tahun). Masing-masing mempunyai nilai satu. Apabila didapatkan nilai 0 atau 1 pasiennya dapat berobat jalan, apabila didapatkan skor 2 dianjurkan untuk dirawat. Jika skor 3 harus dirawat, sedangkan bila skor 4 atau 5 disarankan untuk dirawat di ruangan intensif. ${ }^{1}$ Selengkapnya dapat dilihat pada Tabel 1.

Tabel 1. Skala prognostik: CURB-6 $5^{1}$

\begin{tabular}{ll}
\hline \multicolumn{2}{l}{ Satu poin untuk tiap item } \\
\hline $\mathrm{C}$ & Confusion \\
\hline $\mathrm{U}$ & Urea plasmatic $>44 \mathrm{mg} / \mathrm{dL}(\mathrm{BUN}>19,6 \mathrm{mg} / \mathrm{dL})$ \\
\hline $\mathrm{R}$ & Respiratory rate $\geq 30 \mathrm{bpm}$ \\
\hline $\mathrm{B}$ & Systolic $B P<90 \mathrm{mmHg}$ or diastolic $B P \leq 60$ \\
& mmHg \\
\hline 65 & Age $\geq 65$ years old \\
\hline Skor & Stratifikasi \\
0 atau 1 & Mortalitas rendah $(0,7 \%-2,1 \%)$. Rawat jalan \\
& Mortalitas sedang $(9,2 \%)$. Pertimbangkan \\
2 & rawat inap \\
& Mortalitas tinggi (14,5\%). Rawat inap \\
3 & Mortalitas $>40 \%$. Rawat inap. Pertimbangkan
\end{tabular}

Terapi awal untuk pneumonia diberikan secara empiris. Pemilihan antibiotika empiris pada usia lanjut dipengaruhi oleh derajat kerentaan (frailty), sumber infeksi, adanya faktor risiko infeksi terhadap mikroorganisme resisten, serta tingkat keparahan pneumonia. $^{1}$ 
Pasien tanpa atau dengan frailty memiliki pilihan antibiotika awal yang berbeda. Untuk menilai status frailty dapat digunakan instrumen clinical frailty scale (CFS). Instrumen ini dapat dipakai untuk mendeteksi usia lanjut yang berisiko tinggi mengalami komplikasi dan pemanjangan lama rawat. ${ }^{8}$

Pilihan antibiotika berbeda bagi pasien rawat jalan dan rawat inap. Dosis pertama antibiotika harus diberikan segera. Besarnya dosis dan frekuensi pemberian disesuaikan dengan berat badan dan fungsi ginjal. Potensi interaksi obat juga harus diperhitungkan. ${ }^{1,9}$

Tabel 2. Pilihan antibiotika pada pneumonia komunitas usia lanjut ${ }^{1,9}$

\begin{tabular}{lc}
\hline \multicolumn{1}{c}{ Pasien } & Pilihan antibiotik \\
\hline Rawat jalan & Amoksisilin/Klavulanat atau Sefalosporin \\
generasi kedua & + \\
& Azitromisin atau Fluorokuinolon \\
\hline Rawat inap & Amoksisilin/Klavulanat atau Seftriakson \\
& atau Sefotaksim atau Seftarolin \\
& + \\
Pneumonia & Azitromisin atau Fluorokuinolon \\
\hline Seftriakson atau Sefotaksim atau \\
Seftarolin atau Ertapenem \\
+ \\
Azitromisin atau Fluorokuinolon \\
\pm Linezolid atau Vankomisin \\
\pm B Laktam Antipseudomonas \\
\pm Oseltamivir
\end{tabular}

Pada pasien dengan pneumonia berat, Linezolid atau Vankomisin dipilih apabila terdapat faktor risiko terhadap infeksi Staphylococcus aureus.
Apabila pasien berisiko terhadap bakteri Pseudomonas aeruginosa maka B Laktam Antipseudomonas menjadi pilihan. Selain itu dipertimbangkan juga pola resistensi setempat. ${ }^{1}$

\section{Pneumonia Nosokomial (Hospital Acquired Pneumonia)}

Pneumonia nosokomial (hospital-acquired pneumonia $=H A P)$ adalah pneumonia yang timbul setelah dua hari rawatan di rumah sakit atau selama 10-14 hari setelah pasien pulang rawat. $^{10}$ Pilihan antibiotika untuk pneumonia yang didapat di rumah sakit bergantung kepada waktu timbulnya pneumonia nosokomial. Pasien dengan pneumonia yang timbul sebelum 5 hari dan tanpa faktor risiko dapat diberikan Seftriakson atau Sefotaksim atau Seftarolin atau Fluorokuinolon.

Tabel 3. Terapi antibiotika empiris untuk pneumonia nosokomial $^{1}$

\begin{tabular}{ll}
\hline \multicolumn{1}{c}{ Kelompok pasien } & \multicolumn{1}{c}{ Pilihan antibiotika } \\
\hline Early HAP (<5 hari) & Seftriakson atau Sefotaksim atau \\
tanpa faktor risiko & Seftarolin \\
& atau \\
& Fluorokuinolon \\
\hline Late HAP ( $\geq 5$ hari) & Seftazidim atau Sefepim atau \\
atau dengan faktor & Imipenem atau Meropenem atau \\
risiko & Piperasilin/Tazobaktam \\
& + \\
& Siprofloksasin atau Levofloksasin \\
& atau Amikasin atau Tobramisin \\
& \pm \\
& Linezolid atau Vankomisin \\
\hline
\end{tabular}

Pasien dengan kondisi tertentu memiliki risiko terinfeksi dengan mikroorganisme yang spesifik. Risiko mengalami patogen multidrug-resistant antara lain terdapat pada pasien dengan riwayat penggunaan antibiotika, perawatan $>5$ hari dalam 90 terakhir, dialisis kronik, dan berbagai kondisi lainnya. Pasien yang dirawat di ICU, mendapat terapi steroid jangka lama dan pneumonia nosokomial late onset berisiko untuk terinfeksi kuman Pseudomonas. Selengkapnya dapat dilihat pada Tabel 4. 
Tabel 4. Faktor risiko spesifik untuk pneumonia nosokomial ${ }^{1}$

\begin{tabular}{|c|c|}
\hline Mikroorganisme & Faktor risiko \\
\hline \multirow[t]{9}{*}{ Multidrug-resistant pathogen } & Penggunaan antibiotika sebelumnya \\
\hline & Perawatan $>5$ hari dalam 90 hari terakhir \\
\hline & Meningkatnya kejadian resistensi di RS \\
\hline & Penghuni nursing home \\
\hline & Terapi intravena di rumah (termasuk antibiotik) \\
\hline & Dialisis kronik \\
\hline & Perawatan luka aktif \\
\hline & Kontak dengan pasien terinfeksi multidrug-resistant pathogen \\
\hline & Penyakit imunosupresif dan/atau terapi imunosupresif \\
\hline \multirow[t]{2}{*}{ Batang gram negatif } & Penyakit dasar \\
\hline & Gangguan fungsional \\
\hline \multirow[t]{5}{*}{ Pseudomonas, batang multidrug-resistant } & Perawatan di ICU \\
\hline & Terapi antibiotika sebelumnya \\
\hline & Terapi kortikosteroid kronik \\
\hline & Penyakit paru struktural \\
\hline & Penumonia nosokomial late onset \\
\hline \multirow[t]{4}{*}{ Legionella spp } & Terapi kortikosteroid kronik \\
\hline & Keganasan hematologi \\
\hline & Kontak dengan air tercemar \\
\hline & Riwayat pneumonia nosokomial karena Legionella spp \\
\hline \multirow[t]{7}{*}{ Staphylococcus aureus } & Perawatan di ICU \\
\hline & Riwayat influenza \\
\hline & Kolonisasi atau prevalens methicillin-resistant strains \\
\hline & Trauma kepala \\
\hline & Koma \\
\hline & Diabetes mellitus \\
\hline & Gagal ginjal \\
\hline Aspergillus spp & Terapi kortikosteroid kronik \\
\hline \multirow[t]{4}{*}{ Organisme anaerob } & Oral hygiene yang buruk \\
\hline & Penurunan kesadaran \\
\hline & Manipulasi saluran napas \\
\hline & Pembedahan abdomen \\
\hline
\end{tabular}

Terapi antibiotika diberikan segera setelah diagnosis ditegakkan. Lama pemberian antibiotika sekitar 7-10 hari, dan diberikan selama 14 hari jika ada kecurigaan terhadap infeksi Pseudomonas. ${ }^{9}$

Adapun kriteria untuk merubah terapi injeksi menjadi antibiotika oral antara lain pasien bisa menerima asupan oral, frekuensi jantung kurang dari 100 kali per menit, tekanan darah di atas $90 \mathrm{mmHg}$, frekuensi napas $<25$ kali per menit, kembalinya fungsi kognitif sebelum sakit, dan suhu tubuh $<38,3^{\circ} \mathrm{C}$. Antibiotika oral dapat diberikan apabila saturasi oksigen > 90\% atau tekanan oksigen arteri > 60 $\mathrm{mmHg}$ pada ruangan biasa atau dengan oksigen dosis rendah via nasal kanul, atau telah bisa kembali ke kadar oksigen dasar bagi pasien dengan terapi oksigen jangka panjang. ${ }^{11}$

Pada Tabel 5 disajikan dosis antibiotika serta penyesuaian dosis pada gangguan fungsi ginjal. Antibiotika Azitromisin, Linezolid dan Moksifloksasin tidak memerlukan penyesuaian dosis pada penurunan laju filtrasi glomerulus. ${ }^{9}$ 
Tabel 5. Dosis antibiotika untuk pneumonia berdasarkan fungsi ginjal ${ }^{9}$

\begin{tabular}{|c|c|c|c|}
\hline Antibiotika & Dosis & $\begin{array}{l}\text { Dosis pada gangguan fung } \\
\text { dalam } \mathrm{ml} / \mathrm{menit} \text { ) }\end{array}$ & njal (laju filtrasi glomerulus \\
\hline Amikasin & $15-20 \mathrm{mg} / \mathrm{kg} / 24 \mathrm{jam}$ & $\begin{array}{l}\text { 60-80: 9-12 mg/kg/24 jam } \\
\text { 30-40: 4,5-6 mg/kg/24 jam } \\
\text { 10-20: } 1,5-3 \mathrm{mg} / \mathrm{kg} / 24 \mathrm{jam}\end{array}$ & $\begin{array}{l}\text { 40-60: 6-9 mg/kg/24 jam } \\
\text { 20-30: 3-4,5 mg/kg/24 jam } \\
<10: 1-1,5 \mathrm{mg} / \mathrm{kg} / 24 \mathrm{jam}\end{array}$ \\
\hline $\begin{array}{l}\text { Amoksisilin- } \\
\text { Klavulanat IV }\end{array}$ & $2 \mathrm{~g} / 6-8 \mathrm{jam}$ & $\begin{array}{l}\text { 30-50: } 1 \mathrm{~g} / 8 \mathrm{jam} \\
<10: 500 \mathrm{mg} / 24 \mathrm{jam}\end{array}$ & 10-30: $500 \mathrm{mg} / 12 \mathrm{jam}$ \\
\hline $\begin{array}{l}\text { Amoksisilin- } \\
\text { Klavulanat PO }\end{array}$ & $2 / 0,125 \mathrm{~g} / 12 \mathrm{jam}$ & $\begin{array}{l}\text { 30-50: } 500 \mathrm{mg} / 8 \mathrm{jam} \\
<10: 500 \mathrm{mg} / 24 \mathrm{jam}\end{array}$ & 10-30: $500 \mathrm{mg} / 12 \mathrm{jam}$ \\
\hline Azitromisin IV/PO & $500 \mathrm{mg} / 24 \mathrm{jam}$ & Tidak diperlukan penyesuaian & \\
\hline Sefditoren PO & $400 \mathrm{mg} / 12 \mathrm{jam}$ & 30-50: 200 mg/12 jam & $<30: 200 \mathrm{mg} / 24 \mathrm{jam}$ \\
\hline Sefepim IV & $2 \mathrm{~g} / 8 \mathrm{jam}$ & $\begin{array}{l}\text { 30-50: } 2 \mathrm{~g} / 12 \mathrm{jam} \\
<10: 1 \mathrm{~g} / 24 \mathrm{jam}\end{array}$ & 10-30: $2 \mathrm{~g} / 24 \mathrm{jam}$ \\
\hline Seftriakson IV & 1-2 g/12-24 jam & >10: tidak diperlukan & $<10: \max 2 \mathrm{~g} / 24 \mathrm{jam}$ \\
\hline Siprofloksasin IV & 400 mg/12 jam & 30-50: tidak diperlukan & $<30: 200 \mathrm{mg} / 12 \mathrm{jam}$ \\
\hline Siprofloksasin PO & $500 \mathrm{mg} / 12 \mathrm{jam}$ & 30-50: tidak diperlukan & $<30: 250 \mathrm{mg} / 12 \mathrm{jam}$ \\
\hline Ertapenem IV/IM & $1 \mathrm{~g} / 24 \mathrm{jam}$ & $<30: 500$ mg/24 jam & \\
\hline Imipenem IV & $1 \mathrm{~g} / 6-8 \mathrm{jam}$ & 30-50: $250-500 \mathrm{mg} / 6-8 \mathrm{jam}$ & $<30: 250-500 \mathrm{mg} / 12 \mathrm{jam}$ \\
\hline Levofloksasin & 500 mg/12-24 jam & $\begin{array}{l}\text { 20-50: } 250 \mathrm{mg} / 12-24 \mathrm{jam} \\
<10: 125 \mathrm{mg} / 24 \mathrm{jam}\end{array}$ & 10-20: $125 \mathrm{mg} / 12-24 \mathrm{jam}$ \\
\hline Linezolid IV/PO & $600 \mathrm{mg} / 12 \mathrm{jam}$ & $\begin{array}{l}\text { Tidak diperlukan penyesuaian } \\
\text { dosis }\end{array}$ & \\
\hline Meropenem IV & $1 \mathrm{~g} / 8 \mathrm{jam}$ & $\begin{array}{l}\text { 30-50: } 1 \mathrm{~g} / 12 \mathrm{jam} \\
<10: 500 \mathrm{mg} / 24 \mathrm{jam}\end{array}$ & 10-30: $500 \mathrm{mg} / 12 \mathrm{jam}$ \\
\hline $\begin{array}{l}\text { Moksifloksasin } \\
\text { IV/PO }\end{array}$ & $400 \mathrm{mg} / 24 \mathrm{jam}$ & $\begin{array}{l}\text { Tidak diperlukan penyesuaian } \\
\text { dosis }\end{array}$ & \\
\hline $\begin{array}{l}\text { Piperasilin/tazobakta } \\
\text { m IV }\end{array}$ & 4/0,5 g/6-8 jam & 20-50: $2 / 0,25 \mathrm{~g} / 6 \mathrm{jam}$ & $<20: 2 / 0,25 \mathrm{~g} / 8 \mathrm{jam}$ \\
\hline Tobramisin IV & $4-7 \mathrm{mg} / \mathrm{kg} / 24 \mathrm{jam}$ & $\begin{array}{l}60-80: 4 \mathrm{mg} / \mathrm{kg} / 24 \mathrm{jam} \\
30-40: 2,5 \mathrm{mg} / \mathrm{kg} / 24 \mathrm{jam} \\
10-20: 1,5 \mathrm{mg} / \mathrm{kg} / 24 \mathrm{jam}\end{array}$ & $\begin{array}{l}\text { 40-60: } 3,5 \mathrm{mg} / \mathrm{kg} / 24 \mathrm{jam} \\
20-30: 2 \mathrm{mg} / \mathrm{kg} / 24 \mathrm{jam}\end{array}$ \\
\hline
\end{tabular}

\section{SIMPULAN}

Pemilihan antibiotika pada pasien pneumonia berusia lanjut tergantung kepada jenis pneumonia, berat ringannya pneumonia, dan status frailty. Umumnya besarnya dosis yang diberikan disesuaikan dengan fungsi ginjal usia lanjut.

\section{DAFTAR PUSTAKA}

1. Castillo JG, Sanchez FJ. Pneumonia. Dalam: Halter JB, Ouslander JG, Studenski S, High KP, Asthana S, Ritchie CS, et al, editor (penyunting). Hazzard's geriatric medicine and gerontology. Edisi ke-7. New York: The McGraw-Hill Companies Inc; 2017. hlm. 1957-70.
2. Han X, Zhou F, Li H, Xing X, Chen L, Wang Y, et al. Effects of age, comorbidity and adherence tu current antimicrobial guidelines on mortality in hospitalized elderly patients with communityacquired pneumonia. BMC Infectious Diseases. 2018;18:192.

3. Simonetti AF, Viasus D, Garcia-Vidal C, Carratala J. Management of community-acquired pneumonia in older adults. Ther Adv Infect Dis. 2014;2(1):3-16.

4. Murray MA, Chotirmall SH. The impact of immunosenescence on pulmonary disease. Mediators of inflammation. 2015;ID 692546:1-10.

5. Martono H. Aspek fisiologik dan patologik akibat proses menua. Dalam: Martono H, Pranarka K, editor (penyunting). Geriatri (IImu kesehatan usia 
lanjut). Jakarta: Balai Penerbit Fakultas Kedokteran Universitas Indonesia; 2011.hIm.57-74.

6. Fernandez-Sabe N, Carratala J, Roson B, Dorca J, Verdaguez R, Manresa $\mathrm{F}$, et al. Communityacquired pneumonia in very elderly patients: causative organisms, clinical characteristics, and outcomes. Medicine (Baltimore). 2003;82:159-69.

7. Zalacain R, Torres A, Celis R, Blanquer J, Aspa J, Esteban $\mathrm{L}$, et al. Community-acquired pneumonia in the elderly: Spanish multicentre study. Eur Respir J. 2003;21:294-302.

8. Juma $S$, Taabazuing $M$, Montero-Odasso $M$. Clinical frailty scale in an acute medicine unit: a simple tool that predicts length of stay. Can Geriatr J. 2016;19(2):34-9.
9. Castillo JG, Sanchez FJ, Llinares P, Menendez R, Mujal A, Navas E, et al. Guidelines for the management of community-acquired pneumonia in the elderly patient. Rev Esp Quimioter. 2014; 27 (1):69-86.

10. Cunha BA. Hospital-acquired pneumonia (nosocomial pneumonia) and ventilator-associated pneumonia. Medscape. 2018 Jul (diunduh 10 November 2018). Tersedia dari: https://emedicine.medscape.com/article/234753overview

11. Kaysin A, Viera AJ. Community-acquired pneumonia in adults: diagnosis and management. American Family Physician. 2016;94(9):698-706. 